\title{
Enclosing the Genome: What the Squabbles over Genetic Patents Could Teach Us
} James Boyle ${ }^{1}$

\author{
I \\ Introduction
}

In other writing, ${ }^{2}$ I have argued that we are in the middle of a second enclosure movement. The first enclosure movement involved the conversion of the "commons" of arable land into private property. The second enclosure movement involves an expansion of property rights over the intangible commons, the world of the public domain, the world of expression and invention. Quite frequently it has involved introducing property rights over subject matter -- such as unoriginal compilations of facts, ideas about doing business, or gene sequences -- that were previously said to be outside the property system, uncommodifiable, "essentially common," or part of the common heritage of mankind.

The justifications given for the first enclosure movement were often, though not always, centered on the need for single-entity private property rights over land to encourage development and investment, prevent over and under-use, and in general to avoid the phenomena which we refer to today as "the tragedy of the commons." Enclosure's defenders argue that it helped increase agricultural production and, in the long run, to generate an agricultural surplus sorely needed by a society whose population had been depleted by the mass deaths of the sixteenth century. Private property saved lives. Though "overuse" is rare in the intellectual commons, the rest of the arguments are exactly the ones used to support the second enclosure movement. Intellectual property is needed to encourage development and investment. This argument is made in defenses of drug patents from compulsory licensing claims, in the debates over the creation of new intellectual property rights over data, over business method patents, in the rhetoric of support for the Digital Millennium Copyright Act. $^{3}$

But as this conference shows, and as a cursory study of the newspapers demonstrates, it is

1 C James Boyle 2003. William Neal Reynolds Professor of Law, Duke Law School. This rough draft is made available by the author under a Creative Commons License http://www.creativecommons.org/licenses/by-sa/1.0 The final version is to be published in Advances in Genetics. Thanks to Lauren Dame, Bob Cook-Deegan and Alex Rosenberg for their comments and criticisms. Bob, in particular, should not be held responsible for the results. His comments helped me greatly by making clear out how alien it is to the world of pragmatic intellectual property policy to take the rhetorical structure of a discipline seriously, rather than making arguments within that structure. To the extent that it is now clear that this chapter is not an attack on gene patents, nor an embrace of the critics' arguments, but rather an examination of what the gene patenting debate can teach us about intellectual property scholarship generally, he bears much of the credit.

2 James Boyle, Fencing Off Ideas DaEdalus 13 (Spring 2002); The Second Enclosure Movement and the Construction of the Public Domain 66 LAW AND CONTEMP. PROBLEMS 33 (2003). The Introduction to this chapter draws heavily on the latter article.

3 For details see Boyle, The Second Enclosure Movement, supra note 2 at 33-44. 
the idea that the genome has been turned over to private ownership that has fueled real public attention. Again, the supporters of enclosure have argued that the state was right to step in and extend the reach of property rights; that only this way can we guarantee the kind of investment of time, ingenuity and capital necessary to produce new drugs and gene therapies. To the question, 'should there be patents over human genes?' the supporters of enclosure would answer again, "private property saves lives." Again, the opponents of enclosure have claimed that our common genome "belongs to everyone" that it is "the common heritage of humankind," that it should not and perhaps in some sense cannot be owned and that the consequences of turning over the human genome to private property rights will be dreadful, as market logic invades areas which should be the farthest from the market. What damaged view of the self, what distorted relationship between human beings and the environment, flows from a world in which our genetic code itself is fenced off, made both alienable and alien at the same moment?

The analogy is not perfect, of course; the commons of the mind has many different characteristics from the grassy commons of Old England. Some would say that we never had the same traditional claims over the genetic commons, that the victims of the first enclosure movement had over theirs; this is more like newly discovered frontier land, or perhaps even privately drained marshland, than it is like well-known common land that all have traditionally used. In this case, the enclosers can claim (though their claims are hotly disputed) that they discovered or perhaps simply made usable the territory they seek to own. The opponents of gene patenting turn more frequently than the farmers of the $17^{\text {th }}$ century to religious and ethical arguments about the sanctity of life and the incompatibility of property with living systems. Importantly, too, the genome -- like most of the subjects of the second enclosure movement -- software, data, digital music and text -- is non-rival; unlike the "commons" enclosed during the first enclosure movement, my use does not interfere with yours. I can work it and you can work it too. All of these differences might be relevant, or not, depending on the underlying normative framework we chose to use to assess their property claims. But for the moment, think of the critics and proponents of enclosure - locked in battle; hurling at each other incommensurable claims about progress, efficiency, traditional values, the boundaries of the market, the saving of lives, the disruption of a modus vivendi with nature. We have done this before and perhaps we can learn something from the process. ${ }^{4}$

In my earlier work, ${ }^{5}$ I concentrated on the economic and utilitarian arguments for the second enclosure movement. In sum, I concluded that for a variety of reasons the embrace of the logic of enclosure to justify the expansion of intellectual property across so many fields and so many dimensions was probably a mistake. I argued that while the basic argument for intellectual property protection remains as strong as ever, we have adopted an asymmetric analytic framework which a.) overestimates the applicability of the general logic of enclosure to the special case of intellectual material b.) undervalues the importance of the public domain and the commons to intellectual

4 The analogy to the enclosure movement has been too succulent to resist. To my knowledge, Ben Kaplan, Pamela Samuleson, Yochai Benkler, David Lange, Christopher May and Keith Aoki have all employed the trope, as I have myself on previous occasions. For a particularly thoughtful and careful development of the parallelism see Hannibal Travis, "Pirates of the Information Infrastructure: Blackstonian Copyright and the First Amendment," 15 Berkeley Tech. L.J. 777 (2000). It is also worth noting that Jeremy Rifkin, one of the most outspoken critics of gene patents, has recently turned to this analogy as well. See JEREMY RifKIN, THE BioteCh CENTURY (1998).

5 See note 2 supra. 
production thus c.) focusing only on the (very real) arguments in favor of private property while neglecting the role of the raw materials out of which future innovation is constructed. The resulting policies also d.) overestimate the potential threats and underestimates the potential benefits of the technologies of cheap copying to existing intellectual property rights and e.) fail to take seriously enough the important potential for various types of distributed production, which require a rather different intellectual property environment in order to flourish. Some of those conclusions, a.) and b.) in particular, seem to me strongly applicable to fundamental gene patents -- particularly those which may operate to block or channel future research. Others, for example, e.), have a possible but more dubious relevance.

In this chapter, however, I turn my attention to the other arguments over enclosure, the ones that economic historians - and intellectual property scholars for that matter - tend to note briefly and somewhat dismissively before turning their attention to the real meat of the economic incentives set up by property systems. My question, then, is not "will licensing solve the potential monopolistic problems threatened by fundamental gene patents"? Or "will this particular bit of surgery on the Bayh-Dole Act cure the incentive system so as to encourage fundamental research to yield real products while discouraging "blocking patents" across the arteries of research.?" Those questions are vital ones on which important work has already been done, some of it by my wonderful colleagues at Duke. ${ }^{6}$ But I want to ask a different question, one about the fundamental structure of intellectual property discourse. What can the debate over gene patents teach us about the structure of our discipline, about our pattern of inquiry? What does that debate reveal about the both the selective focus and the selective blindness in the way that intellectual property scholars analyze the question? In short, this article treats the debate over gene patents as a rhetorical case study, a place to reflect on the limits of our discipline. It does not attempt to enter that debate on one side or the other.

\section{II You Can't Own a Gene}

Like the debate over the first enclosure movement, the debate over the enclosure of the genome is not one debate but many. The commonly heard phrase "you can't own a gene" turns out to cover a remarkably broad range of arguments and beliefs. These arguments are not necessarily consistent, of course, and intellectual property lawyers would disclaim many of them as being beyond their purview. In addition, the arguments vary importantly depending on the subject matter of the patent; the debate is not merely, or even most interestingly, about patents on genes. Claims to patents on different types of genetic sequences raise very different issues. What's more, I mean here to catalogue types of objections, rather than to investigate them in any detail, which requires

\footnotetext{
${ }^{6}$ John Walsh, Ashish Arora, \& Wesley Cohen, The Patenting of Research Tools and Biomedical Innovation, draft (on file with author); Arti K. Rai \& Rebecca S. Eisenberg, Bayh-Dole Reform and the Progress of Biomedicine, 66 LAW \& CONTEMP. Probs. 289, 289 (Winter/Spring 2003). For the seminal study of the early days of the genome project and the conflicts over gene patenting, which goes beyond economic considerations to consider some of the ethical objections made, see Robert Cook-DeEgan, The Gene Wars: Science, Politics And the Human GenOme (1994).
} 
painting with a distressingly broad brush. Sweeping all of these qualifications aside for a moment, let me attempt a breathless summary of the most commonly heard objections to genetic patents. My hope is that, for the cognoscenti, it may be useful to review of territory so well-known it is seldom examined. For the newcomer, this may serve as a rough guide to the territory, to be deserted later in favor of more detailed maps.

The Sacred: "You can't own a gene because it would be against the tenets of my faith. God wrote those sequences of C, G, A \& T. It is heresy, or at least plagiarism, for you to claim to do so." In a more modest version, the accusation is not heresy or plagiarism, but simply ludicrous hubris. Who are you to claim a patent on a human genetic sequence, even a "purified" version of a genetic sequence with the introns spliced out? ${ }^{7}$ (A version of this argument will reappear as an argument about whether genetic sequences fit the statutory and constitutional requirements of patent law.)

The Uncommodifiable: "You can't own a gene because it would be immoral; some things should be outside of the property system - babies, votes, kidneys; if they become commodified the market seeps into aspects of our lives that should be free from market logic." " Sometimes the proponents of this argument rely on a teleological view of human flourishing, at other times on a theory of 'spheres of justice' within a liberal state, at still others they conjure up a dystopian future in which transgenic sub-human creatures are traded as chattels, our reverence for thinking beings having been undermined by the twin expansions of genetic science and market logic. This view in turn, segues into...

\footnotetext{
7"In the 19th century, another great debate ensued with abolitionists arguing that every human being has intrinsic value and "God-given rights" and cannot be made the personal commercial property of another human being. The abolitionists' argument ultimately prevailed, and legally sanctioned human slavery was abolished in every country in the world where it was still being practiced...Now, still another grand battle is unfolding on the eve of the Biotech century. This time of the question of patenting life - a struggle whose outcome is likely to be as important to the next era in history as the debate over usury, slavery, and involuntary indenture have been to the era just passing. In May of 1995, coalition of more than 200 religious leaders, including the titular heads of virtually every major Protestant denomination, more than 100 Catholic bishops, and Jewish, Muslim, Buddhist, and Hindu leaders, announced their opposition to the granting of patents on animal and human genes, organs, tissues, and organisms.... The coalition, the largest assemblage of U.S. religious leaders to come together on an issue of mutual interest in the 20th century, said that the patenting of life marked the serious challenge to the notion of God's creation in history. How come life be defined as an invention to be profited from by scientists and corporations when it is freely given as a gift of God, asked the theologians? Either life is God's creation or a human invention, but it can't be both. " JEREMY RIFKIN, THE BIOTECH CENTURY 64 (1998).

8 "Now, the most intimate Commons of all is being inclosed and reduced to private commercial property that can be bought and sold on the global market. The international effort to convert the genetic blueprints of millions of the years of evolution to privately held intellectual property represents both the completion of a half millennium of commercial history closing of the last remaining frontier of the natural world." Rifkin at 41. Not all agree. "The reductive objectification of life has enlarged understanding of vital processes, but it does not relegate living creatures to the category of objects. We understand that animals are physics and chemistry. But we can realize that they are sentient creatures and grant them rights that they do not inherently possess. We can realize that people perform physical and chemical functions, but we need not treat them as physical and chemical machines." Daniel Kevles, Vital Essences and Human Wholeness: The Social Readings of Biological Information 65 S. CAL L. REV 255, 277.
} 
The Environmental Ethic: "You can't own a gene; to do so is to embrace a system in which nature, even our own nature, is to be manipulated, traded and commodified." While the environmentalist critics of gene patenting generally have concerns that stretch beyond the human genome alone, they see it as a particularly revealing example. Many argue that the frame of mind which would permit such property rights is one which displays a breathtaking willingness to tinker with delicate environmental systems. ${ }^{9}$ Others claim that the availability of such juicy state-granted monopolies establishes a set of incentives which positively invite corruption of the legislative process and the undermining of rational environmental policy.

The Common Heritage of Mankind: "You (alone) can't own a gene because the genome belongs to all of us. Like the deep sea bed, the history of the human species, or outer space the genome is 'the common heritage of mankind,' one of the quintessential resources that must be held in common." ${ }^{10}$ Sometimes this view rests on some Teilhard de Chardin-esque teleology of the human species, while at other times it represents a straightforward appeal to international distributive justice. If the technologically advanced countries can secure property rights over resources that only advanced technology will reach, goes the argument, then patent rights over the genome are a kind of second colonial expansion. The moon or the deep sea bed or the genome should not become the next place to be claimed for Queen Isabella of Spain.

The Rights of Sources: "You can't own this gene because I owned it first. My genetic information is my property. Your gene sequences came originally from a source and the source's claims should be recognized, either instead of or as well as, the person seeking the patent." This objection is sometimes raised on behalf of those who unwittingly provided genetic material to a research project

9 "Biotechnology is not simply another mechanical or chemical procedure aimed at making the world better for us. With biotechnology, we are not reshaping matter, but harnessing life. We take a 3,500 million year old process that shaped our existence and the existence of every other organism on the planet and restructure it for our benefit. We need a more thoughtful conceptualization of this technology and more careful control over its development and use than is allowed by gung ho biopatent policies. Biotechnology does offer promise and hope for bettering human life and perhaps other life as well. Opposing biopatents does not entail opposing biotechnology. Organism and gene patents should be resisted not because biotechnology should be resisted, but rather because these biopatents are a morally dangerous and inappropriate way of thinking about and encouraging biotechnology." Ned Hettinger, Patenting Life: Biotechnology, Intellectual Property, and Environmental Ethics, 22 B.C. ENVTL. AfF. L. REV. 267, 304 (1995).

10 "The application of the Common Heritage concept to the genome would balance the interests of developed and developing countries, thus holding true to the traditional purpose. As stated previously, most developing countries are opposed to patenting genes, and consider it a form of neo-colonialism. Because the genome technically belongs to the citizens of LDCs to the same extent as citizens of the developed countries, the Common Heritage Principle is necessary to balance the property rights of both LDCs and developed country citizens despite their different interests." Melissa L. Sturges, Who Should Hold Property Rights to the Human Genome? An Application of the Common Heritage of Humankind, 13 Am. U. Int'l L. Rev. 219 251-2 (1997); See also J.M. Spectar, The Fruit of the Human Genome Tree: Cautionary Tales About Technology, Investment, and the Heritage of Humankind, 23 LOY. L.A. INT'L \& COMP. L. REV. 1. On both sides of these arguments, the background assumptions are often hard to parse. "From the perspective that genes are our common, universal possession symbolizing humankind's collective heritage, genes seem an inappropriate substance in which to grant individual intellectual property rights. Yet, in light of patent availability in most other scientific research fields, denying gene patents appears to be inequitable." Patricia A. Lacy, Gene Patenting: Universal Heritage vs. Reward for Human Effort, 77 OR. L. REV. 783. 
from which some desirable genetic sequence was derived. ${ }^{11}$ At other times, the claim comes from the families of those with a particular genetic disorder. Here the genetic material was donated knowingly but the families are using property and contract claims to ensure that the development of tests and treatments for the disorder protects the interests of the patients involved. ${ }^{12}$ Other variants include attempts by particular groups or populations whose genetic information is somehow of interest, to prevent what they see as "gene piracy."13

Patentable Subject Matter: "You can't own a gene because you can't patent it; it doesn't satisfy the basic requirements of the patent law and the constitution." The challenges differ depending on the type of genetic material involved. The main objections are as follows:

Novelty: Many genetic patents cover material that is not "novel" because they are in fact patents on naturally occurring products; if patents are being given for laborious transcription of a naturally occurring substance, that hardly meets the novelty standard. Even if the sequences are "purified," for example by removing non-coding segments, critics argue that this should not meet the standard for novelty, and might also run into problems because of the "obviousness" of the process.

Non-obviousness: In general, the standard methods of genetic sequencing are such that each step in the process of cell line isolation, purification and sequencing may be obvious from the prior step in the process. One of the larger concerns being expressed here, as in the discussion of novelty, is that intellectual property rights are being given in raw data, based on the labor required to produce it. Such "sweat of the brow" claims are supposed to be anathema to the law of copyright and patent, while the subject matter here - genetic sequences - seem to be straightforward arrangements of factual data; a subject matter that the Constitutional patent and copyright power does not reach.

Utility: Some of the genetic patents have been shotgun claims over large number of sequences, without clear knowledge as to what function these sequences actually have. Others cover sequences the main function of which is as probes in research so that their "utility"is as research intermediaries rather than useful end products.

As is often (and appropriately) the case in patent law, debates about the meaning of the statutory and constitutional requirements for patents frequently devolve into questions about the

\footnotetext{
${ }^{11}$ The classic case is that of John Moore. See James Boyle, Shamans Software And SpleEns; Law AND THE CONSTRUCTION OF THE INFORMATION SOCIETY 97-107 (1996).

12 "When the Terry family of Sharon, Massachusetts, realized that disease researchers didn't have the family's interests at heart, they took control of their bodies intellectual property. The result? Do-it-yourself patenting was born.. Boyd (who hasn't been funded by PXE International) agreed with Terry's morally driven, but practical, view that the laws of this market left patients no choice but to seek control of the intellectual property. "This was a way to ensure that that the test isn't going to cost an arm and a leg," notes the scientist....By laying legal claim to their bodies, the Terrys have advanced research enough that doctors genuinely may be able to arrest the progress of PXE before their children go blind, which often happens to patients in their late 30s. Ian Terry, now 11, already has initial signs of eye trouble. At the very least, the parents' organizing has inspired Elizabeth Terry, now 13, to say she'll become a patent lawyer -though her mother says she's also flirting with criminal law. No doubt, Elizabeth should pursue what she wants: By the time she graduates from law school, the patient advocacy movement should have plenty of patent attorneys on its side." Matt Fleischer, Patent Thyself AMERICAN LAWYER June 2001.
}

${ }^{13}$ Kara H. Ching, Indigenous Self-Determination in an Age of Genetic Patenting: Recognizing an Emerging Human Rights Norm, 66 FORDHAM L. REV. 687. 
effects on innovation that a particular interpretation of the subject matter requirements would have. Since the patent system is, in its constitutional and theoretical origins, guided explicitly by utilitarian concerns, almost all would concede that the ultimate benchmark for any interpretation of the subject matter requirements should be its effect on the encouragement and promotion of the progress of the useful arts. ${ }^{14}$ In the case of patents on genetic sequences, this means defining the requirements of patentable subject matter with the assumption that those requirements exist so as to encourage both abstract research and final practical deployment of some therapy or test. Thus discussions of patentable subject matter tend to segue into the free-standing debate that already exists about the effects of genetic sequence patents on innovation.

Innovation Policy: "You can't own a gene because if you did so, it would actually hurt research and innovation, the very things you are trying to encourage." Here the arguments are particularly subtle and nuanced. The basic difference between the genetic commons and the earthy commons of old England, at least from an innovation policy point of view, is its non-rivalrous quality. The danger to be sought here is not unrestrained overuse, but underinvestment in research and product development. What's more, as is generally the case, intellectual property deals with a subject matter in which future products are generally assembled from the pot-shards of prior efforts. Each property right tacked onto your stream of intellectual outputs increases the cost of my stream of intellectual inputs. Even if, in principle, I could either "invent around" prior protected innovation, ${ }^{15}$ or secure licenses on those chunks which it proved impossible to bypass, the transaction costs involved in the process of identification, weighing the relative costs of inventing around, negotiating and so on, might undercut a large number of innovations at the margin. ${ }^{16}$ It is the work of intellectual property scholars to work at this point of delicate equipoise; the balance between, on the one hand, failing to guarantee sufficient protection (or government funding) in order to encourage both research and commercialization, and on the other, slowing down the process of research and commercialization

14 Unfortunately, the Court of Appeals for the Federal Circuit,(CAFC) which handles patent appeals nationwide, does not appear to share this point of view. To this external observer it seems that the CAFC lurches from formalism to utilitarian analysis and back again, guided by some muse of its own. [For a related critique see Arti K. Rai Specialized Trial Courts: Concentrating Expertise on Fact 17 Berkeley Tech. L.J. 877 (2002)] The court also appears gratifyingly indifferent to academic opinion; many distinguished patent scholars appeared to think the State Street bank opinion [State St. Bank \& Trust Co. v. Signature Fin. Group, 149 F.3d 1368, 1373 (D.C. Cir. 1998)] was the jewel in the crown of bad patent decisions, [See eg Robert P. Merges, As Many as Six Impossible Patents Before Breakfast: Property Rights for Business Concepts and Patent System Reform 14 Berkeley Tech. L.J. (1999).] Yet despite the storm of academic protest, one Judge on the court recently remarked in clear self-satisfaction, that everyone was clearly now comfortable with the Court, so that perhaps its jurisdiction should now be expanded to cover copyright as well! Being ignored like this is clearly good for the otherwise non-existent humility of legal academics, but since the court appears instead to take its lead from the patent bar, which has a something of a self-interest in maximalist protection, one wonders whether it is also a prescription for a good patent law jurisprudence.

15 "Inventing around" is normally a safety valve in intellectual property policy, the possibility of which operates to reduce the drag on progress caused by prior rights, and to create downward pressure on the price of licenses. One particular (though disputed) concern with the human genetic patents is the extent to which there may be no feasible way to innovate around a particular patent, precisely because of the fundamental quality of the subject matter.

${ }^{16}$ Michael A. Heller \& Rebecca S. Eisenberg, Can Patents Deter Innovation? The Anticommons in Biomedical Research, SCIENCE, May 1, 1998, at 698. 
with a thicket of property rights. The best work on the subject refines this point of balance; pointing out counter-intuitive processes at work within it, ${ }^{17}$ expanding on institutional dynamics, bringing in the insights of other disciplines, and of empirical research on the innovation process. ${ }^{18}$

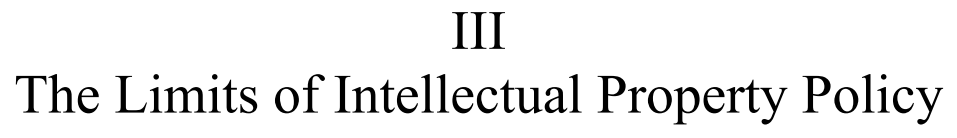

As promised this has been a somewhat breathless summary of the arguments about the patents over human genetic sequences. It is far from complete. In particular, I have not expanded on the many thoughtful counterarguments that can be raised to each of these objections, because I do not mean to enter the debate so much as to point out something about it. It is my hope that the summary I have given helps us to see that the academic intellectual property debate has tended to be much narrower than the popular or policy debate. First, patent scholars and patent lawyers have largely viewed all but the last two sets of criticisms as outside their purview ${ }^{19}$; the legislature decides what is and is not patentable, they argue, so to address arguments about the immorality, or environmentally hurtful quality of gene patents to the Patent and Trademark Office, to the patent bar or even to patent scholars is to mistake the institutional function of those entities. The role of patent specialists is to make positive claims about what the law is, and restricted normative claims about how current or proposed patent rules will further the goals of the patent system, which in turn are understood in means-ends terms as a utilitarian calculation of the best way to foster technologically usable "progress." Thus patent scholars do not eschew normative analysis altogether; most of them simply restrict it to the consensus utilitarian goals of the system.

Patent scholars will happily debate the claim that current PTO utility guidelines, or the PTO's practices in reviewing patents on Expressed Sequence Tags, are moving intellectual property rights too far "upstream" in the research cycle in a way that will actually discourage future research and innovation. But for most of them, claims about the effect of commodification on attitudes towards the environment, about distributive justice and the common heritage of mankind or the moral boundaries of the market are simply outside the field. (The claims about the relationship of the genome to the realm of the sacred, of course, are even more so.) Ironically, some of those who in other areas of scholarship might be more inclined to criticize the utilitarian, means-ends metric

17 See eg. Pamela Samuelson \& Suzanne Scotchmer, The Law and Economics of Reverse Engineering, 111 YAle L.J. 1575, 1608-13 (2002); F. Scott Kieff, Property Rights and Property Rules for Commercializing Inventions, 85 MinN. L. REV. 697 (2001).

18 See eg Wesley Cohen et al., Protecting Their Intellectual Assets: Appropriability Conditions and Why U.S. Manufacturing Firms Patent (or Not), National Bureau of Economic Research, Working Paper No. 7552 (2000); Mark Lemley \& John Allison, Who's Patenting What? An Empirical Exploration of Patent Prosecution, 53 VANDERBILT LAW REVIEW 2099 (2000).

19 I would happily acknowledge that there are salutary exceptions to this claim. See eg Molly A. Holman \& Stephen R. Munzer, Intellectual Property Rights in Genes and Gene Fragments: A Registration Solution for Expressed Sequence Tags, 85 IowA L. REV. 735 (2000). I would argue, however, that the general claim holds true. 
as partial, or as a "thin and unsatisfactory epistemology" through which to understand the world ${ }^{20}$ are, in the patent field, particularly wedded to it. A brief digression is necessary to explain why.

\section{The Bipolar Disorders of Intellectual Property Policy}

At its crudest, the basic division in the intellectual property field is between maximalists or high protectionists, on the one hand, and minimalists, or those with a heightened concern about the public domain, on the other. While actual positions are considerably more nuanced, if one had to construct an "ideal type" of these two positions, it would run something like this. The maximalists favor expansive intellectual property rights. They tend to view exemptions and privileges on the part of users or future creators as a tax on rights holders and have sympathy for thinly disguised 'sweat of the brow' claims. They exhibit a kind of economic bipolar disorder: being deeply pessimistic about market functioning around potential public goods problems in the absence of intellectual property rights, and yet strikingly, even manically, optimistic about our ability to avoid transaction costs and strategic behavior "anti-commons effects" that might be caused by the presence of intellectual property rights.

The minimalists have exactly the opposite set of attitudes. They start from the presumption that the baseline of American law is that 'the noblest productions of the human mind are upon voluntary disclosure to others, free as the air to common use. ' Thus intellectual property rights, understood as "monopolies," look like dangerous state granted subsidies, which should be confined in amount and extent to the minimum demonstrably necessary. Minimalists exhibit their own economic bipolarity; they are often deeply optimistic about the ability of creators and innovators to adapt business methods so as to gain returns on innovation without recourse to legal monopolies. (For example, by being "first to market," relying on the provision of tied services to generate revenue, or by adopting physical and virtual methods of exclusion in order to avoid the underlying public goods problem.) They are also relatively optimistic about the impact of technology on the innovation marketplace; they see new technologies that lower the cost of copying, such as the internet or PCR, as providing benefits as well as costs to rights holders, so that every reduction in the cost of copying need not be met with a corresponding increase in the level of protection. On the other hand, the minimalists are deeply, almost tragically, pessimistic about the ability of rights holders to bargain around the potential inefficiencies and transaction costs that their rights introduce into the innovation process. Here, private action to avert potential market failure seems much harder, for some reason, than it did when we were discussing the adoption of possible business methods to gain a return on innovation.

The maximalists' arguments are, in general, weaker, because the minimalist account is more faithful to thoughtful innovation economics and to the historical and constitutional traditions of American intellectual property law. More importantly, years of relentless expansion in intellectual property rights mean that the disputed frontier is now very far out indeed; maximalists must now defend rights that are, frankly, silly. However what the maximalists lack in argumentative power, they more than make up in political power; their views are extremely hospitable to a variety of film, recording, software and pharmaceutical companies who can supplement dubious economic analysis with indubitable economic payments -- in many cases, payments direct to legislators. More

\footnotetext{
${ }^{20}$ This description of the philosophical shortcomings of economic analysis is, amusingly enough, Richard Posner's. RICHARD POSNER, THE PROBLEMS OF JURISPRUDENCE xiv (1990) (citing the words of Paul Bator).
} 
interestingly, there are also some philosophical reasons why we tend to undervalue the public domain, ${ }^{21}$ and why strong intellectual property rights breed even stronger intellectual property rights. ${ }^{22}$

To be sure, the minimalist and maximalist I have just described are exaggerated ideal types, seldom met in their pure form. (And certainly no such caricatured scholars are present in this volume I am sure, indeed a number of the scholars here have written important pieces that point out the dangers of both under and over protection. ${ }^{23}$ ) Still the distinction catches something important. Now notice the irony. Minimalists might seem like the natural allies of those who are skeptical about gene patents for religious, environmental, moral or distributive reasons. Yet inside the world of intellectual property policy, the minimalists are often the ones who are put in the position of insisting on the need to confine analysis to the economic need for intellectual property rights as incentives to progress. Normally, this happens when a minimalist confronts some intellectual property claim built on Lockean labor principles, or Hegelian ideas of personality, or even just based on the fecklessly unattractive behavior of some alleged "infringer" who is scarfing up a work created with the investment of much sweat and capital.

In the face of these appealing arguments, the minimalists insist sternly that the constitution and the American tradition of intellectual property law forbid us such normative appeals. We must confine ourselves to incentives, no matter how hard-working or morally attractive the potential recipient of intellectual property rights, only the encouragement of the next creator is important. Thus when the issue turns to gene patents, the minimalists are happy to point out the dangers in moving intellectual property rights too far upstream, or the need to keep some teeth behind the utility, non-obviousness and novelty requirements. Yet their relentlessly utilitarian framework makes it much harder for them to consider arguments that fuel much of the general popular, journalistic, and policy debate, even when those arguments are not deployed to argue for the extension of intellectual property rights, but for their circumscription. Having insisted on the necessity of a means-ends analysis focused on producing incentives to progress it is much harder to engage the claims about the moral limits of the market in a liberal democracy, or the argument that the growth economics of a consumer society so permeates our assumptions as to make it impossible to consider the environmental consequences of our property systems. To be sure, there is excellent scholarly work that avoids this potential pitfall, but nevertheless the ambit of discussion in the intellectual property debate is a relatively narrow one, and I believe this is at least one of the reasons why.

21 See eg James Boyle, Shamans Software And SpleEns; Law AND the Construction of The Information Society(1996). James Boyle, A Politics of Intellectual Property: Environmentalism for the Net. James Boyle, A Politics of Intellectual Property: Environmentalism for the Net?, 47 DuKE L.J. 87 (1997).

${ }^{22}$ James Boyle, Cruel, Mean or Lavish?: Economic Analysis, Price Discrimination and Digital Intellectual Property 536 VANDERBILT LAW REVIEW 2007 (2000).

23 Compare Rebecca Eisenberg, Proprietary Rights and the Norms of Science in Biotechnology Research, 97 Yale L.J. 177 (1987) \& Heller \& Eisenberg, supra note 15. 


\section{Reasons To Be Narrow: Take 3}

So far I have argued that the debate over gene patents allows us to reflect on a curious fact: a number of factors have come together to produce a remarkably narrow disciplinary self-conception in the world of intellectual property scholarship. Thus, for example, I argued that our concentration on the clash between maximalist and minimalist visions of intellectual property has produced as an unintended side-effect a curious methodological tunnel vision. The critical scholars most likely to question the ambit of new rights are, paradoxically, firmly wedded to the notion that the only legitimate rubric for intellectual property policy is the maximization of innovation. All other normative criteria are to be exiled beyond the pale of the discipline.

But is narrowness such a bad thing? First, are these debates worth participating in? For example, one does not have to be a logical positivist to believe that policy debates based on religious faith tend to collapse fairly quickly into mutually incompatible thunderous denunciations. There might be a principled deal to be brokered between the Darwinians and the theists on the status of the human genome, but the odds are against it. Does this caution hold true for most of the objections to genetic patents?

Second, even to the extent that there are fruitful intellectual debates to engage with here, do intellectual property scholars have anything to add to them? What do we know of environmental ethics, or the moral limits of market under liberal capitalism, or of the distributional or internationalist commitments raised earlier? Shouldn't the cobbler stick to his last?

Third, isn't this whole question moot? We may believe that there are reasons, both inside and outside the legal system, why genetic patents should not have been granted, but the genie is now out of the bottle; at least in the United States. A multi-billion dollar industry has been erected on the premise that quite fundamental genetic patents are available. In practice, neither the Supreme Court nor Congress nor the PTO is going to upset that premise, even if some have their doubts about whether it was ever correct either as a matter of law or as a matter of desirable innovation policy.

These are weighty objections, but I think that there is a response - at least a partial response to each of them.

First, let me concede that the religious objections present the hardest case for the benefits of disciplinary openness (and are thus frequently used as a proxy to suggest that none of the noneconomic arguments are worth considering, a conclusion that hardly follows.) Let me note, though, the fact that debates turn on matters of non-falsifiable religious faith is hardly anything new to the world of legal scholarship. Indeed, it is often the case that such debates - abortion is the obvious example - attract an astounding amount of scholarly attention, some of it actually premised on the claim that the controversy is faith-based; some scholars have argued the fact that a policy is faithbased, or that the moral claims raised are incommensurable, has concrete legal or constitutional ramifications. ${ }^{24}$ In other words, the religious components of fundamental policy debate have just as frequently in the past been reasons for scholarly intervention - wise or unwise though that intervention might be. One might also note that it is hard to draw a clean line between religious faith-based systems and secular moralities which developed out of them or away from them, and which also rest on a priori claims. And if it is hard to justify our conceptual apartheid even in the strongest case, straightforward claims to religious faith, then surely it must be very hard indeed to

${ }^{24}$ See eg Ronald Dworkin, Freedom's Law: The Moral Reading of the American Constitution 29 (1996). 
justify exclusion of the environmental, distributional and other normative concerns, which certainly form an important part of more conventional property scholarship. Put differently, if one reverses the question and asks, 'Is it appropriate for intellectual property scholarship to exile all forms of morality other than wealth-maximizing utilitarianism?' then the boundary lines of our discipline look considerably less justifiable. But even if the frankly religious component of the debates drops out - a result which would not displease me, I confess - or is admitted only through some "purifying" secular filter of abstract moral philosophy, there is still much of substance that remains, much that fits within the ambit of the constitutional basis of American intellectual property law, yet that lies beyond the current bounds of intellectual property scholarship, policy and debate.

Think for a moment of more conventional property scholarship and policy debates. Imagine that we were debating whether or not to allow the commodification of non-reproducible organs, such as kidneys or corneas. Or imagine a debate about the sale of contracts of employment, or the question of ownership of Indian relics. Think of a discussion of the possible partition and sale of America's national parks. Or, for that matter, of the deep sea bed, the surface of the moon, or of licenses to pollute. There are those, of course, who would pursue these questions solely through a narrow utilitarianism, in some framework of wealth maximization or theoretical Pareto superiority. We all have such colleagues and I am sure they are very dear to us. But most of us would find such an approach a mark of a sadly crabbed legal and philosophical imagination, would we not? This is not to say that one would neglect the economic questions, in fact they would often play a vital role, but they would surely do so in the context of a much wider analysis. Such analyses would in all likelihood be marked by explicit consideration of the effects of the property regime on human dignity, and on the environment, by consideration of the legitimacy of traditional property claims, by discussion of the requirements of international distributive justice. Even within the utilitarian analysis, they would be marked by a skepticism about the normative force of extrapolations from the existing distribution of wealth, and would in all likelihood involve a frank choice among multiple possible measures of efficiency. Is a discussion of patent rights over the genome so different that it warrants about a completely different set of methodological assumptions? Does being an intellectual property scholar offer a license to be parochial?

What of the second objection, that modesty should cause intellectual property experts to stay away from the environmental, moral or distributive objections to genetic patents? Modesty is a great virtue to be sure, but one must note that it is altogether an uncharacteristic one for legal scholars. In fact, following their discipline's longstanding imperialistic urges, legal scholars have exercised eminent domain over a remarkable range of questions and specialties - from Rawlsian moral theory through game theoretic analysis, to literary theory, neo-classical economics, deconstruction, queer theory, and chaos theory. Why stop here? It may be that intellectual property is the only place where one can find a modest legal scholar, though that would not be the descriptive term that immediately leaps to my mind to characterize the group. But we surely need some explanation of why the arguments for methodological modesty are so dominating here that they win almost without discussion, and yet so weak elsewhere.

More particularly, as I just pointed out, if one looks at parallels in the scholarship over real and personal property, one finds no such reticence. Debates over commodification and the limits 
of the market are commonplace, ${ }^{25}$ as are discussions of the rights of indigenous peoples, or the extent to which property has a fundamental status within our political tradition that demands greater constitutional protection. ${ }^{26}$ If they can do it, why can't we? It is worth pointing out that the link between environmental policy and property law has been particularly fruitful; both in terms of practical explorations of the intersection, in the law of nuisance for example, and theoretical explorations of the juncture in the context of such issues as tradeable emissions rights, ecosystem services or 'the substitutes for a land ethic.' 27 There is no reason to believe that the same number of insights, provocations and engagements could not be found in the fight over the enclosure of the intangible genetic commons, the intersection between intellectual property policy and environmental policy or the search for a Leopoldian 'substitutes for a genome ethic. ${ }^{28}$

The third objection is that the entire question is moot because a multi-billion dollar industry has been built on the premise of gene patents. Even if those were initially of questionable validity, and I think there is a respectable argument in law and policy to say that this is the case, no court is now going to upset the financial arrangements that have already been built. This is an important and legitimate pragmatic consideration. Still, scholars are not supposed to give up their inquiries even if there are strong practical reasons why the social arrangements they are challenging look particularly stable. This point is, or at least should be, axiomatic. Moreover, the insights that come from engaging the broad range of arguments for and against genetic enclosure are not limited to some up or down vote on gene patents. The same issues are presented at every level of the analysis, from the debate over the scope of stem cell patents, the PTO's utility guidelines, the exercise of governmental march-in rights, the negotiation of the next round of the TRIP's, the revision of BayhDole, the debate over database protection and so on and so on. Those issues continue to arise and it will ill-serve us if we have a double-decker structure of policy debate about them; a lower deck of tumultuous popular and non-legal arguments about everything from the environment to the limits of the market, and a calm upper-deck which is once again fine-tuning the input-output table of the innovation process. We need a fusion of the two; or at least a staircase between them.

\section{IV \\ Reconstructing Scholarship}

Let me assume optimistically that a couple of the arguments I have made here cause you at least a moment's thought before they are rejected. Perhaps you find it hard to explain the disparity in methodological breadth between property scholarship and intellectual property scholarship when it comes to questions of commodification. Alternatively, perhaps you are struck by the fact that even much of the most "critical" intellectual property scholarship tends to be relentlessly utilitarian, whether the question being debated is the expansion of rights or their circumscription. It could even

\footnotetext{
25 For an uncommon example, see, Margaret Jane Radin, Contested Commodities (1996).

${ }^{26}$ See e.g. Richard A. Epstein, Takings: Private Property And the Power of Eminent Domain (1985).

${ }^{27}$ Aldo Leopold, A SAnd County Almanac 210-211 (1949).

${ }^{28}$ See infra note 33.
} 
be that you notice how seldom intellectual property scholarship deals explicitly with questions of distributive justice, or even with more expansive definitions of economic efficiency. Those questions, after all, are meat and drink to scholars of tort law, property law, taxation and so on, even those operating in a largely economistic framework. Can they be irrelevant here? Let us say, in other words, that you are willing to entertain the possibility that the methodological boundaries of the discipline might be a little narrow and that the gene patenting controversy could illustrate some of that narrowness. I would count this chapter a success if it raised even this much of a doubt.

The next, entirely reasonable, question is, 'so what would we be looking at if we agreed with you?' What kinds of potentially productive study are suggested if we take seriously some of the points I have tried to developed here? It is a daunting task first to imagine and then defend an entire body of scholarship. Nevertheless, here are two lines of inquiry that strike me as particularly fruitful and, while they go far beyond the debate over gene patents, seem to me provocatively to be suggested by some of the arguments we find there.

1.) Questioning and refining the ideal of perpetual innovation: Like most scholars of intellectual property, I use innovation as my touchstone. For both constitutional and economic reasons, the ideal of continued innovation in science, technology and culture lies at the heart of the discipline. We worship at the church of innovation. We take it as an a priori good. But is the concept as unproblematic as our work would make it seem? In other contexts, environmentally inspired economics has raised powerful concerns about the different but related ideal of perpetual growth; is our ideal to build a market that makes more and more stuff, and in the process makes us (unequally) richer so we can afford to buy more stuff, fueling yet another cycle of productive expansion and relentless consumption? The environmentalists ask us whether such a conception of economics is environmentally sustainable, or suited to promote human flourishing. It would be hard to disagree that our conceptions of economics and growth policy are stronger as a result of their objections. Are there a similar set of questions about the ideal of perpetual innovation?

To put it more precisely, the environmental critique of perpetual growth depends on 1.) an empirical challenge to the assumption of infinite resources, 2.) an epistemological challenge to the notion that human welfare is reducible to consumer surplus, and 3.) a deontological or teleological challenge to the 'form of life' implied by consumer materialism. But for most scholars, the response to these thoughtful challenges is not to reject growth as a goal. It is, rather, to talk of sustainable development, to disaggregate the notion of growth and talk about those forms of growth that are desirable. Can we, should we, do the same thing with innovation, seeking to disaggregate it and fine-tune our policies to achieve the types of innovation we wish, whether to preserve the environment or to promote 'human flourishing,' or honor the logic of the original position, or to take account of the diminishing marginal utility of wealth? Is our discipline's goal of innovation really reducible to the attempt to "develop new stuff that sells?"

For those who practice the economics of the Chicago school, current revealed consumer preferences (based on the existing distribution of wealth and the pattern of ability and willingness to pay which that distribution yields) have an almost totemic power. This is an absolutely central point. It is not simply preferences in the abstract that generate our measure of value: doubtless parents of children with sleeping sickness in developing countries have an overwhelming "preference" for the development of a drug that would offer a cure. But preferences in the Chicago model are measured only at the conjunction of ability and willingness to pay: the distribution of 
wealth thus dramatically effects the "value" of the goods desired. If one ignores the question of a justification for the existing distribution of wealth, one can assume that it is only our current pattern of preferences (based on our current distribution of wealth) that gives rise to "neutral" or "scientific" descriptions of human welfare. Attempts to interfere with the pattern of innovation called for by those preferences, (for example, by shifting research away from male pattern baldness and towards malaria and sleeping sickness) represent a "political choice" or a preference for "equity" over "efficiency," and thus possibly a market distortion and resulting welfare loss. The decision blindly to follow the demand dictated by the current distribution of rights and wealth does not represent such a political choice. (To which one can only respond, "Humbug!") Thus the Chicago school economist would effectively answer that innovation $i s$ reducible to the attempt to develop new stuff that sells. This is a neutral account of innovation and an appropriate guide to intellectual property policy. Any other notion, for example, seeking those forms of innovation that might be called for by a more equal distribution of wealth, or those forms which hold the best prospect of preserving the biosphere, represents a contentious political choice and is an inappropriate focus for scholarly inquiry. Scholars should not be choosing among or between preferable types of innovation, but simply seeking to promote innovation -- understood as a black box which takes its preference inputs from the existing distribution of wealth, and its constraints from the existing pattern of rights and regulation.

But the Chicago school account is, to use a precise term of art vouchsafed to me by my children, 'bogus.' There is no neutral account of innovation, or of efficiency. Note well, please, that I am not saying we must "supplement" our analysis of neutral efficiency with warm, fuzzy distributional concerns. Our conceptions of efficiency (and thus of innovation) themselves already contain strong, and frequently unannounced or justified distributional assumptions. We must, and we already do, pick between different visions of that concept. For example, we choose between those visions of efficiency which do and those which do not rely on ability and willingness to pay as the sole measure of value. Some measures of valuation take "asking price" rather than offering price as their criterion; if you had the right to have sea otters floating off Alaska, how much would I have to pay you to give up that right? Wealth thus becomes less important. The decision of whether it is "efficient" to engage in development that threatens the sea otters changes dramatically - not because we have added some marginalised notion of distributional equity as an annex to our efficiency analysis, but because all efficiency analyses implicitly contain such assumptions already. The same point applies to more technical efficiency criteria. Do we pick Kaldor-Hicks efficiency with its notion that a change is economically efficient if the winners could compensate the losers and still be better off, while not actually requiring that they do engage in compensation? Or do we apply Pareto superiority, where a change is only "efficient" if the winners could and do actually compensate the losers?

Now apply this critique to the world of intellectual property. Different notions of efficiency and market demand for particular innovations will obviously yield very different patterns of efficient innovation policy. More complex methodological assumptions about the scope of the analysis too, will influence the outcome. For example, our analysis of innovation is influenced by market structures and ideals of progress that are partly caused by the very rules we are analyzing. We must choose whether to hold those structures constant, or to put them, too, under the microscope of analysis. Consider, for example, the disparate treatment of investment in compiling factual data on the one hand and investment in invention or expression on the other. Are these differences to be 
taken as given, as exogenously determined rights which structure the market we study, or as a part of the field to be questioned? Our work is influenced by implicit selections between types of innovation already prefigured in the legal doctrine. Consider, for example, the treatment of pure research tools under the utility guidelines, or the different treatment of innovative parody and satire in copyright law. Some types of innovation are to be hailed, others not. My point is that, implicitly, scholars are already selecting among types of innovation. ${ }^{29}$ We hail certain market structures as more innovative, when what we really mean is that they promote more desirable forms of innovation when judged against some other metric - based on a particular and contentious conception of efficiency, distributional justice, or what have you. These other metrics, however, are generally assumed rather than defended.

The result of these patterns of thought is particularly unfortunate. To the extent that we discuss distribution at all, we relegate it to a second class status, after the real scientific analysis, devoted to maximising innovation, has taken place. But this makes no sense. We know - or we should know - from the cognate debates over the meaning of efficiency in economic analysis, that our definitions of innovation already incorporate contentious distributional assumptions. Whether something is "innovation," like whether something is efficient, will depend on complex judgements about how to incorporate the impact of existing distributions of wealth, including distributions of prior legal rights, on the "valuations" that the analysis uses as criteria. We know this when we pick between Kaldor-Hicks and Pareto superior measures of "efficiency," when we incorporate or do not incorporate the diminishing marginal utility of wealth, or the endowment effects of behavioral economics, into our tax policy. We know it when we decline to find that it is efficient to move the resource of a glass of water to the mildly overheated rich man rather than the pauper dying of thirst. We know it when we use contingent valuations of "what it would cost to make you give up X right, or drug" rather than "what could you afford to pay for X right, or X drug" as our measure. We know it when we decide whether the pollution driven destruction of wildlife for which there is no market is inefficient, which in turn depends on what types of contingent valuation we use to measure that loss. Why then do we not know it in the world of intellectual property scholarship.

If the gene controversy, where all these issues are forcibly thrust to the surface of the debate, forced us to disaggregate innovation, and then to articulate and defend the precise incarnation of it that we believe to be justified - whether on environmental, distributional or deontological grounds - then it would have done us a favor. It is striking to see the uncritical way that appeals to big "P" Progress and big "E" Efficiency are accepted in our discipline, where in other areas of legal scholarship there is much more of an attempt to clarify which type of efficiency or which type of progress is being appealed to, an attempt which must reach outside the charmed circle of economic analysis in order to be meaningful. To be sure, early Chicago school law and economics scholarship talked as if there were one uncontestable vision of efficiency, and all other visions of the concept

${ }^{29}$ I take it that some economists are perfectly prepared to agree to certain versions of this argument. See eg Brett Frischmann Innovation and Institutions: Rethinking the Economics of U.S. Science and Technology Policy 24 VT. L. REV. 347 (2000). Yochai Benkler's work comes closest towards unpacking the meanings of innovation and selecting among and between them based on an analysis that is informed by economics, but goes beyond the narrowly economic. Yochai Benkler, A Political Economy of the Public Domain: Markets in Information Goods vs. The Marketplace of Ideas

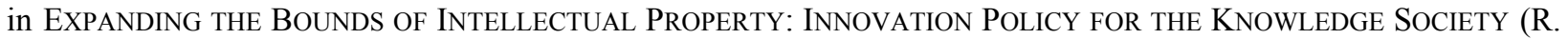
Dreyfuss, D. Zimmerman, H. First eds.) (2000); Free as the Air to Common Use: First Amendment Constraints on Enclosure of the Public Domain 74 NYU Law Review 354 (1999) 
could be exiled to the touchy-feely world of "equity claims"; claims which were always to be pursued somewhere else than in the current analysis. But it would be hard to find many contemporary scholars who echo those claims, or who treat wealth maximization within the current distribution of wealth as an unproblematic definition of efficiency. Is that not, though, what we do all to often in intellectual property scholarship -- at least when we worship at the church of innovation without clarifying what implicit choices about types of desirable innovation are being concealed by the very structure of our analysis? To say this is not automatically to nominate any particular successor notion of innovation. My own preference would be for considerably more scholarship that measures our system of current innovation against one that, in questions of basic human need, such as access to essential medicines, stipulated a certain minimum valuation to human life, even among the global poor. There are many possible solutions to the failures and inefficiencies this analysis would reveal in our current intellectual property system - ranging from supplementing the patent system with government bounties or prizes, to offering dual zone patents, to directly subsidizing research. Intellectual property scholars have an extremely valuable role to play in working out the bugs in such solutions and they are less likely to play that role while they are in the thrall of the black box model of innovation. And this will be true whatever measure of innovation we choose to articulate and defend. This leads to my second suggestion.

2.) From Public Goods to Public Choice: We look at intellectual property through a lens constructed around the focal point of rational choice theory. We care deeply about the structure of incentives that it sets up, the possible free rider effects, moral hazards and so on. But we are curiously reticent in turning that lens back on the structure of incentives that intellectual property policy sets up in the policy-making process itself.$^{30}$ We should study the market for intellectual property legislation with the same care and rigor that we display in studying the market for intellectual property. To put it differently, one environmentalist critique of gene patents is that they create a powerful incentive for rights-holders to drive state scientific policy towards the utilization of the technologies in which the rights holders have exclusive rights, and do so quickly, before the patent term expires, regardless of whether the environmental consequences of those technologies are well understood. This kind of phenomenon ought to be well within the intellectual property scholar's field of inquiry.

More generally, we need models of the market for intellectual property legislation that can help us understand how to build structural protections of the public interest into the policy making process itself. Intellectual property is a legal device to avoid a "public goods" problem, meaning the problem of providing adequate incentives to produce goods which are non-rival and nonexcludable. But there are also a different variety of "public goods" in the market for intellectual property legislation. We know that legislation built around the self-interest of existing and aspirant monopolists will protect a variety of private goods, namely those of the firms and interests at the table. We know also that it will fail to protect certain kinds of interests - most notably those of large numbers of unorganized individuals with substantial collective, but low individual, stakes in the

30 For a general background see MAXWELL L. STEARNS, PUBLIC CHOICE AND PUBLIC LAW; READINGS AND COMMENTARY (1997); Daniel A. Farber \& Philip P. Frickey, The Jurisprudence of Public Choice, 65 TEX. L. REV. 873 (1987). For a similar suggestion about intellectual property policy see Arti Rai, Addressing the Patent Gold Rush: the Role of Deference to PTO Patent Denials 2 Wash. U. J.L. \& Pol'y 199, 215, note 51 (2000). 
matters being discussed. It will fail to protect the interests of businesses that, as Jessica Litman puts it, are "outsiders who can't be at the negotiating table because their industries haven't been invented yet." 31 This will be even more true if those businesses are likely to challenge the business plans of the companies that are at the table. It will fail to protect the public domain, even as a source for future creativity, except in the limited cases where those around the table can clearly see that their particular form of production will work better with a rich commons-based system, rather than around a private property system tilted to give their particular form of production an advantage.

These are the dysfunctions that we know our market for intellectual property legislation will yield. Why then, do we not spend some of the time we currently invest trying to remedy dysfunctions in information and innovation markets, instead trying to think of remedies for the dysfunctions in our legislative process? How about an intellectual property ombudsman to represent the interests of the public and the public domain? Or a required "Information environment impact statement" by the GAO justifying each new grant of monopoly right in terms of its long term economic effects? Doubtless there are better ideas than these, but it is the focus on the policy making process that I wish to defend. Again, attention to the gene patenting controversy proves instructive. It may be that the complaints of the people on the bottom of the bus have more to teach those of us on the top than we would like to admit.

\section{Conclusion}

I started by comparing the current progress of intellectual property expansion over the human genome to the English enclosure movement. As with the first the enclosure movement, we are faced with a conflicting array of claims - claims about the essential common-ness of the property in question, or the moral and traditional reasons why it should not be shifted to individual ownership, claims about the effect of newfound property rights on environmental attitudes, claims about the limits of the marketplace, about economic effects, about encouragement of innovation and so on and so on. As with the first enclosure movement, some of these claims are essentialist or romantic or just analytically sloppy. As with the first enclosure movement, we have available to us a cooler language of economic incentives that promises a calmer and smoother discussion about the encouragement of progress. (Though the economic arguments for the second enclosure movement strike me as considerably weaker than those for the first.) And as with the first enclosure movement, to retreat from the full range of issues into those calmer smoother waters would be a mistake, even if we ended up supporting the furthest reaching extensions of property rights currently being proposed.

In this article, I have tried to summarize - without endorsing - a broad range of criticisms of gene patenting. My point was not to say that this broad range of criticisms was correct, indeed I find many of them unpersuasive. Nor was it to reject the analytical structure of innovation economics that forms the backbone of intellectual property scholarship. Instead, I used the gene patenting debate as an example to make the larger point that intellectual property scholars are

${ }^{31}$ Jessica LitMan, Digital Copyright (2001) 
mistaken to write off most non-utilitarian criticisms as outside their purview; concentrating instead only on a positive exegesis of patent law and a restricted normative exegesis of which patent policy will best ensure continued research and development of commercially desirable products. Even if one is unconvinced by Rifkin or the environmentalists, in other words, when one focuses on the pattern of disciplinary exclusion, rather than the particular substantive arguments, it becomes apparent both how narrow and how contentious our disciplinary assumptions are. What's more, I argued, the major professional division among intellectual property scholars - that between maximalists and minimalists - has the strong, but probably unintended effect of helping to reinforce this narrowness over the methodological tenets of the discipline. The minimalists are those with the strongest incentive to challenge the expansion of intellectual property rights over the genome. Yet, because of the structure of the rhetoric in the discipline, they are also those most committed to the claim that only utilitarian arguments about the encouragement of future innovation are legitimate parts of the discourse. Minimalists are used to fighting off covert sweat of the brow claims, concealed appeals to natural right, and Hegelian notions of personality made manifest in expression - all deployed to argue that rightsholders should have their legally protected interests expanded yet again. Against these rhetorics, they insist on both constitutional and economic grounds that the reason to extend intellectual property rights can only be the promotion of innovation. When we turn to the question of whether there are non-economic reasons for curtailing the reach of patents over genetic material, their hard-wired reflex is to restrict their analysis to the same utilitarian domain. Beyond the debate between maximalists and minimalists, the gene patenting controversy throws other articles of faith and other shibboleths into doubt; from the various possible presumptions behind the idea of perpetual innovation to the assumed operation and dysfunction of the political process. Thus, I concluded, we have much to learn from the gene wars even though they may currently seem to yield more heat than light.

I think most intellectual property scholars will find this claim unconvincing. Told that they must supplement a discipline in which answers seem possible -- even if disputed -- with greater attention to debates in which they have much less familiarity and in which answers seem much more contested, they will understandably cavil. What's more, the intellectual biographies of many patent scholars mean that they find the intersection of a particular complex technology with a set of different innovation markets to be a much more personally hospitable terrain than the broader landscape I am suggesting.

I cannot prove that they are wrong, of course. For epistemological reasons, if nothing else, the proof of this pudding is in the eating. But I will offer two analogies to suggest that a broader debate about genetic patents within intellectual property scholarship would be of particular benefit.

First, consider the analogous effect of environmental thinking on both debates within, and the analytical structure of, tangible property scholarship. ${ }^{32}$ The increase in the breadth of the analysis, the need for a multi-generational framework, the importance of externalities, the complexity and interrelationship of the natural systems within which schemes of public and private law land regulation intersect - all of these have been highlighted by the brush with environmental concerns. Disciplines do not develop in a vacuum; in this case the analytical toolkit itself has been changed by the encounter. Even the practitioner of a "just-the-facts-Ma'am" style of property

${ }^{32}$ Carol Rose's work illustrates my point here particularly well. 
scholarship, uncomfortable with the fuzziness and enthusiasm of all these tree-huggers, has seen his discipline improved in the process. Though consideration of environmental themes does not logically require us to be more self-conscious about our notions of "efficient" property policy, it has undoubtedly had that effect. There is, I would suggest, no reason to believe that the same thing would not be true of intellectual property scholarship as it confronts the very real questions posed by the consequences to environmental policy of patents on genetic material, including human genetic material. And this thought, in turn, suggests that in other areas the broader debate over genetic patents may have much to teach intellectual property scholars, in the same way that the debate over commodification changed property scholarship in the 80's and 90's. In particular, we intellectual property scholars need to grapple more thoroughly than we have with the limitations as well as the advantages of the utilitarian, progress-enhancing analytical framework we adopt. In other areas of scholarship, we are much more willing to point out the limits of utilitarian analysis, the weakness of a "willingness and ability to pay" model of social worth, the impact of wealth effects on the efficiency calculus, the intergenerational moral concerns hidden by the framework of growth economics, the problems with always assuming endogenous preferences, or exogenously determined rights. Just as we may have more to offer the debate over gene patents than a careful analysis of effects of exclusive rights at different points in the research stream, so too the broader debate over gene patents may have things to show us about the relative complacency of our methodological assumptions. ${ }^{33}$ Ironically, as I suggested earlier, this point may be particularly important, and particularly difficult, for the minimalists.

For a second analogy, consider the justice claims that have recently caused 'access to essential medicines' to become a fundamental part of drug patent policy both domestically and internationally. Again, these are a set of issues that fit poorly within conventional intellectual property scholarship; but the arguments are not mere exhortations to take drugs away from companies and hand them over the poor and the sick. The essential medicine questions are not simple, either economically or institutionally and - after some initial reticence - the academy now seems to be turning its eyes to the complicated points of treaty interpretation, regional institutional design, international price discrimination, and alternative patent regimes that this particular and real moment of human suffering forces us to think about. Can we really believe that our scholarly focus will be somehow weaker as a result of the forced encounter with claims of distributive justice and human rights? In fact, with any luck, the intensity of feeling about a particular controversy over AIDS drugs may actually force us to acknowledge the single greatest weakness behind a patent driven drug development policy; a patent driven system for drug development will, if working correctly, deliver drugs on which there is a high social valuation - measured in this case by ability and willingness to pay. To put it another way, to have a patent-driven drug policy is to choose to deliver lots of drugs that deal with male-pattern baldness, but also with real and important diseases:

${ }^{33}$ I have struggled with this point particularly in my scholarship on the public domain. In that scholarship, I rely heavily on the basic tools of innovation economics. But I am always troubled when I read these lines from Aldo Leopold, from a chapter of Sand County Almanac entitled "Substitutes for a Land Ethic." "One basic weakness in a conservation system based wholly on economic motives is that most members of the land community have no economic value... When one of these non-economic categories is threatened, and if we happen to love it, we invent subterfuges to give it economic importance... It is painful to read those circumlocutions today." ALDO LEOPOLD, A SAND COUNTY ALMANAC 210-211 (1949). 
rheumatoid arthritis, various cancers and heart disease. It is to choose not to have a system that delivers drugs for tropical diseases, or indeed for any disease which is suffered overwhelmingly by the national or global poor.

To say this is not to condemn drug patents; it is rather, to suggest precisely the two lines of inquiry I argued for in this article. First, if our goal is truly to help to eliminate human suffering, then we should spend more time thinking about alternative and supplementary ways of encouraging pharmaceutical innovation beyond the drug patent system. Second, when we talk about innovation and progress in the intellectual property system, we quickly and easily substitute some universal imagined ideal of Progress for the actual specific version of "progress" towards which our current distribution of entitlements and rights will push us. Many policies that might seem justified by the promotion of large "P" progress, might seem more questionable if they were instead pushing us towards the specific vision of progress held latently within the pattern of demand established by our current distribution of rights and wealth. To quote Amartya Sen, "there are plenty of Pareto optimal societies which would be perfectly horrible places to live." 34

Now if these lessons can be taught us in a concrete and unforgettable way by the debate over drug patents, is there any reason to believe that the larger debate over gene patents will offer us any less insight, or any less provocation? It could be, of course, that the end result would be exactly the same; perhaps all of us would find our conclusions unchanged, even if we were a little more critical about worshiping at the church of innovation, even if we clarified our definitions of that concept and of the notion of efficiency that underpins it, even if we broadened our scholarly focus to include the kind of institutional and environmentalist inquiries I suggest here, and made our discussion of commodification a little more similar to that which occurs in conventional property scholarship. Perhaps this change in methodology would leave our substantive positions unchanged, though I doubt it.. Perhaps its effects would only be found in other areas, such as the essential medicines question, or the question of the goals of basic science policy, or the question of the redesign of the institutional framework through which intellectual property policy is made. But even if all that were true, the gene patenting debate could still teach intellectual property scholars a set of lessons we sorely need. At least, that is, if we have the courage to enter it.

\footnotetext{
34 The source was an interview with an uncomprehending MSNBC interviewer at the time of Sen's receipt of the Nobel prize. The reader will have to trust the author's faulty memory for the precision of the quote.
} 